\title{
KINERJA BIROKRASI PEMERINTAH DAERAH (STUDI KASUS: MASALAH PENGETAHUAN DAN KETERAMPILAN APARATUR DI SEKRETARIAT DAERAH KABUPATEN BANTAENG)
}

Nurhidayah ${ }^{1}$, Mappamiring ${ }^{2}$, Burhanuddin ${ }^{2}$

\author{
${ }^{1}$ Program Studi Ilmu Pemerintahan Fakultas Ilmu Sosial Dan Ilmu Politik \\ ${ }^{2}$ Program Studi Ilmu Administrasi Negara Fakultas Ilmu Sosial Dan Ilmu Politik \\ Universitas Muhammadyah Makassar \\ Il. Sultan Alaudin No. 259 Makassar 90221 \\ Tlp. 0411-866972 ext. 107. Fax. 0411-865588
}

\begin{abstract}
This study aimed at knowing the impact of the knowledge and skills problem in Secretariat of Bantaeng regency as a form of Bureaucracy Pathology. The findings of this study were expected to provide more information about the condition of bureaucracy in the secretariat of Bantaeng regency and its bureaucratic pathologies that have disturbed the function of the bureaucracy as a tool of society in achieving an ideal goal. Academically, the findings of this study were expected to provide more values which can then be compared with other scientific studies, especially under the problem of bureaucratic pathology. The method used in this study was descriptive qualitative supported by quantitative data in the form of tables offrequency with library research (library research) and field studies (field research) as the techniques of data collection. Meanwhile, the sampling technique used in this research was the total sampling in which the samples were taken subjectively who considered representative for this study. The results showed how the problem of knowledge and skill under the indicators: 1). Level of education, 2). Training, 3). Experience gave a negative influence on the performance of civil servants. Finally, this influences the incompetence of bureaucratic to run the roles and functions or in term of Bureaucracy Inconsistency.
\end{abstract}

Keywords: performance, local government bureaucracy

\section{ABSTRAK}

Penelitian ini bertujuan untuk mengetahui dampak dari masalah pengetahuan dan keterampilan di Sekretariat Kabupaten Bantaeng sebagai salah satu bentuk Patologi Birokrasi. Hasil dari penelitian ini diharapkan mampu memberi informasi lebih tentang kondisi birokrasi di sekretariat daerah kabupaten Bantaeng serta patologi birokrasinya yang selama ini cukup mengganggu fungsi birokrasi sebagai alat masyarakat dalam mencapai tujuan ideal. Dari segi akademik, hasil dari penelitian ini diharapkan memberi nilai tambah yang selanjutnya dapat dikomparasikan dengan penelitian-penelitian ilmiah lainnya, khususnya yang mengkaji masalah patologi birokrasi. Metode penelitian yang digunakan adalah deskriptif kualitatif yang didukung dengan data kuantitatif dalam bentuk tabel frekuensi, dengan teknik pengumpulan data studi kepustakaan (library research) dan studi lapangan (field research). Sedangkan teknik penarikan sampel yang digunakan adalah sample total yaitu mengambil sampel secara subjektif yang dianggap representatif. Dari hasil penelitian menunjukkan bagaimana masalah pengetahuan dan keterampilan dengan indikator: 1). Tingkat pendidikan, 2). Pelatihan, 3). Pengalaman, memberi pengaruh negatif terhadap kinerja pegawai negeri sipil. Pada akhirnya pengaruh ini mengakibatkan ketidak mampuan birokrasi menjalankan peran dan fungsinya atau yang disebut dengan istilah Inkonsistensi Birokrasi.

Kata Kunci: kinerja, birokrasi pemerintah daerah 


\section{A. PENDAHULUAN}

Kecenderungan birokrasi dan birokratisasi pada masyarakat modern benar-benar dipandang memprihatinkan, sehingga digambarkan adanya ramalan mengenai makin menggejalanya dan berkembangnya praktek-praktek birokrasi yang paling rasionalpun tidak bisa lagi dianggap sebagai kabar menggembirakan, melainkan justru merupakan pertanda malapetaka dan bencana baru yang menakutkan (Blau dan Meyer, 2000: 3). Menurut Islamy (1998:8), birokrasi di kebanyakan negara berkembang termasuk Indonesia cenderung bersifat patrimonialistik : tidak efesien, tidak efektif (over consuming and under producing), tidak obyektif, menjadi pemarah ketika berhadapan dengan kontrol dan kritik, tidak mengabdi kepada kepentingan umum, tidak lagi menjadi alat rakyat tetapi telah menjadi instrumen penguasa dan sering tampil sebagai penguasa yang sangat otoritatif dan represif. Meskipun sudah menjadi gejala yang sangat umum, ternyata pada setiap konteks sistem budaya masyarakat, secara empirik birokrasi dan birokratisasi terlihat dalam pola perilaku yang beragam.

Apabila ditelusuri lebih jauh, gejala patologi dalam birokrasi, menurut Sondang P. Siagian (1989:30), bersumber pada lima masalah pokok. Pertama, persepsi gaya manajerial para pejabat di lingkungan birokrasi yang menyimpang dari prinsip-prinsip demokrasi. Hal ini mengakibatkan bentuk patologi seperti: penyalahgunaan wewenang dan jabatan menerima sogok, dan nepotisme. Kedua, rendahnya pengetahuan dan keterampilan para petugas pelaksana berbagai kegiatan operasional, mengakibatkan produktivitas dan mutu pelayanan yang rendah, serta pegawai sering berbuat kesalahan. Ketiga, tindakan pejabat yang melanggar hukum, dengan "penggemukan" pembiayaan, menerima sogok, korupsi dan sebagainya. Keempat, manifestasi perilaku birokrasi yang bersifat disfungsional atau negatif, seperti: sewenang-wenang, pura-pura sibuk, dan diskriminatif. Kelima, akibat situasi internal berbagai instansi pemerintahan yang berakibat negatif terhadap birokrasi, seperti: imbalan dan kondisi kerja yang kurang memadai, ketiadaan deskripsi dan indikator kerja, dan sistem pilih kasih.

Adanya tantangan birokrasi di bidang pendidikan maka pengetahuan dan keterampilan para birokrat sangat perlu untuk ditingkatkan namun yang terjadi di Sekretariat Daerah Kabupaten Bantaeng ternyata timbul beberapa penyakit birokrasi yang lebih akrab disebut dengan istilah patologi birokrasi. Salah satu patologi birokrasi yang muncul ialah masalah pengetahuan dan keterampilan di mana para pegawai di kantor tersebut beberapa persen bukanlah tenaga-tenaga yang memiliki pengetahuan dan keterampilan tinggi sesuai dengan tuntutan tugasnya. Kemudian penempatan yang tidak didasarkan pada pertimbangan-pertimbangan objektif dan rasional seperti: latar belakang pendidikan, pelatihan yang pernah diikuti, pengalaman serta minat dan bakat pegawai yang bersangkutan. Salah satu akibatnya adalah potensi yang terdapat dalam diri pegawai tidak dikembangkan dan tidak pula dimanfaatkan sebagaimana mestinya.

Pada gilirannya, tingkat pengetahuan dan keterampilan yang rendah berkaitan pula dengan berbagai aspek manajemen sumber daya manusia dalam birokrasi yang bersangkutan. Misalnya, apabila proses rekruitmen dan seleksi tidak dilakukan dengan baik, akibatnya ialah bahwa yang diterima menjadi pegawai bukanlah tenaga-tenaga yang memiliki pengetahuan dan keterampilan tinggi sesuai dengan tuntutan tugas yang dipercayakan kepadanya. Segi lain ialah, penempatan yang tidak didasarkan pada pertimbanganpertimbangan yang objektif dan rasional, seperti latar belakang pendidikan, pelatihan yang pernah diikuti, pengalaman, minat dan bakat pegawai yang bersangkutan. Salah satu akibatnya ialah bahwa potensi yang terdapat dalam diri para pegawai tidak dikembangkan dan tidak pula dimanfaatkan sebagaimana mestinya. Masalah pengetahuan dan keterampilan akan menjadi semakin rumit, apabila dalam birokrasi tidak terdapat program pendidikan dan pelatihan yang betul-betul dikaitkan dengan tuntutan tugas dan tantangan yang diperkirakan akan dihadapi oleh birokrasi yang bersangkutan. 
Permasalahan lain yang laten dalam birokrasi adalah secara nasional sumber daya aparatur belum memiliki kualifikasi sebagaimana yang diharapkan. Salah satu indikasinya adalah tingginya ketidaksesuaian antara jenjang pendidikan yang ditempuh dengan tempat/posisi kerja.

Penulis tertarik meneliti terhadap persoalan di atas dengan harapan hasil penelitian dapat memberikan hasil dan berguna bagi Kabupaten Bantaeng.

\section{B. KERANGKA TEORITIS}

Istilah birokrasi mulai diperkenalkan oleh filosof Perancis Baron de Grim dan Vincent de Gournay dari asal kata "bureau" yang berarti meja tulis dimana para pejabat (saat itu) bekerja dibelakangnya (Budi Setyono, 2004 : 10). Secara etimologi istilah birokrasi berasal dari kata bureau (bahasa Perancis) yang berarti "meja tulis" dan kratos (bahasa Yunani) yang berarti "pemerintahan". Pengertian yang demikian kemudian berkembang seiring dengan waktu (Sastroatmodjo, 1995 : 189).

Menurut Taliziduhu Ndraha, istilah birokrasi berasal dari dua akar kata, yaitu bureau (burra, kain kasar penutup meja), dan-crazy, ruler. Keduanya membentuk kata breau-crazy. selanjutnya, pemerintahan birokratik adalah pemerintahan tanpa partisipasi pihak yang diperintah (M. Crozier dalam Riggs, 1971:97). Birokrasi diartikan sebagai sifat atau perilaku pemerintahan, yaitu sifat kaku, macet, berlikuliku, dan segala tuduhan negatif terhadap instansi yang berkuasa (Kramer, 1977:88), dipertegas oleh Riggs sebagai bureaupothology. Ketiga, birokrasi sebagai tipe ideal organisasi. Birokrasi dalam arti ini dianggap bermula dari teori yang dikemukakan oleh Max Weber tentang konsep sosiologik rasionalisasi aktivitas kolektif (Taliziduhu Ndraha, 2003 : 513).

Konsepsi birokrasi dalam ilmu sosial merupakan usaha-usaha modern untuk mendorong ke arah proliferasi konsep lebih lanjut. Untuk menjaga perspektif perkembangan konsep birokrasi tersebut, penulisan tentang birokrasi modern akan ditelaah berdasarkan konsep yang telah biasa digunakan, mengacu pada berbagai afiliasi bidang ilmu, kecendeungan teoritik dan strategi-strategi konseptual atau elaborasi dari pengertianpengertian birokrasi yang telah baku.

Gagasan birokrasi yang memandang birokrasi sebagai suatu mekanisme sosial yang memaksimumkan efisiensi dan juga sebagai suatu bentuk organisasi sosial yang memiliki ciri-ciri khas merupakan hubungan antara atribut-atribut suatu lembaga sosial dan akibatakibatnya, kemudian diarahkan pada pendefinisian birokrasi sebagai organisasi yang memaksimumkan efisiensi dalam administrasi yang selanjutnya digunakan secara netral untuk mengacu kepada aspek-aspek administrasif dari organisasi-organisasi sebagaimana dikemukakan oleh Peter Blau (Albrow, 1989 : 83).

Peter Leonard mendefinisikan birokrasi merupakan suatu hal yang sekedar mengacu pada susunan kegiatan-kegiatan yang rasional dan secara jelas yang diarahkan pada pencapaian tujuan-tujuan organisasi. Gagasan tenteng birokrasi ini bertolak belakang dengan konsep birokrasi pada umumnya yang identik dengan inefisiensi administrasi. Selanjutnya Herbert Simon menambahkan bahwa; "Gagasan rasionalitas yang bersifat heuristik dan normatif menerangkan kalau tidak mungkin untuk menetapkan prosedurprosedur apapun yang benar-benar selalu berasal dari gagasan efisiensi organisasi". Hal demikian tidak berarti bahwa penelitian ke arah organisasi rasional di dalam masyarakatmasyarakat yang berbeda unyuk menemukan beberapa bentuk organisasi (Albrow, 1989 : 83-84).

Max Weber menganggap bahwa birokrasi dianggap menjalankan peranan sebagai pahlawan. Dia menyatakan bahwa birokrasi mampu mencapai tingkat efisiensi yang paling tinggi dan bentuk administrasi yang paling rasional karena birokrasi merupakan pelaksana pengendalian melalui pengetahuan (Sastroatmodjo, 1995 : 190), Max Weber (1922) mengemukakan pemikirannya bahwa birokrasi rasional adalah sebuah konsepsi birokrasi yang muncul atas dasar kaidahkaidah otoritas hukum, bukan karena sebab lain, seperti otoritas tradisional maupun otoritas kharismatis (Budi Setiono,2003 : 39). 
Victor Thompson mengatakan bahwa "Birokrasi tidak mengenal belas kasihan. Tidak pula mengenal cinta kasih". Dikatakan selanjutnya bahwa birokrasi itu bersifat "impersonalitas" (Miftah Thoha, 2002 : 52), begitu pula dengan H.J Laski (2000: 12) mengungkapkan bahwa birokrasi merupakan penyebar penyakit rutin dalam administrasi, mengorbankan fleksibilitas demi peraturan yang kaku, mengulur-ulur proses pembuatan keputusan dan menolak melakukan eksperimen. Laski memandang bahwa birokrasi merupakan ancaman bagi pemerintahan demokratis. Kaum birokrat secara terus-menerus memperluas ruang lingkup kekuasaan mereka, sedangkan pengendalian terhadap mereka sulit untuk dilakukan (Sastroatmodjo, 1995 : 90).

Karl Marx menganggap bahwa birokrasi adalah alat kelas yang berkuasa, yaitu kaum borjuis dan kapitalis untuk mengeksploitir kelas proletar. Birokrasi adalah parasit yang eksistensinya menempel pada kelas yang berkuasa dan dipergunakan untuk menghisap kelas proletariat (Priyo Budi Santoso, 1999: 16), Kemudian M. Crozier dalam penelitiannya tentang birokrasi di Perancis adalah sebagai berikut : "organisasi birokratik adalah suatu organisasi yang tidak dapat mengoreksi tingkah lakunya dengan cara belajar dari kesalahan-kesalahan" (Priyo Budi Santoso, 1999 : 19), Kramer mengartikan birokrasi sebagai sifat atau perilaku pemerintahan , yaitu sifat kaku, macet, berliku-liku, dan segala tuduhan negative terhadap instansi yang berkuasa (Taliziduhu Ndraha, 2003 : 513)

Max Weber dalam Budi Setiyono (2004), memandang bahwa fenomena birokrasi dapat dilihat dalam konteks teori "social action". Dimana menurut dia, semua aktivitas manusia pada dasarnya digerakkan oleh maksudmaksud tertentu (meanings). Supaya bisa dipahami suatu aksi atau aktivitas, maka maksud dan motivasi yang ada di belakang aktivitas itu harus pula dimengerti. Max Weber mengidentifikasi beberapa tipe-tipe aktivitas yuang dibedakan oleh maksud yang ada di belakangnya, yakni : Afektif (affective), Tradisional (traditional), Nilai rasional (value rational), Instrumental-rasional (instrumentallyrational). Setiap anggota dalam suatu birokrasi tidak lepas dari kekuasaan dan kewenangan yang sifatnya warisan dari pendahulunya yang memiliki ikatan hubungan keluarga atau dengan kata lain memiliki hubungan darah dari pendahulunya yang mendapat pengakuan dan kekaguman dari pengikutnya pada khususnya dan anggota masyarakat luas pada umumnya. Otoritas kharismatik yang dimiliki oleh pemimpin suatu birokrasi akan menjadi suatu kekuatan apabila manusia yang memiliki kharismatik itu, juga memiliki kemampuan pengetahuan teoritis terutama di bidang kepemimpinan yang diperoleh melalui proses belajar. Demikian pula sebaliknya jika otoritas yang dimiliki oleh seseorang hanya mengandalkan kharismatik yang diwarisi oleh pendahulunya, maka akan memiliki kelemahan dalam rangka melaksanakan otoritas itu dalam suatu birokrasi ( Makmur, 2007 : 86 ).

Max Weber memandang bahwa birokrasi rasional sebagai unsur pokok dalam rasionalisasi dunia modern yang baginya jauh lebih penting dari seluruh proses sosial. Diantara yang lainnya, proses ini mencakup ketepatan dan kejelasan yang dikembangkan dalam prinsip-prinsip memimpin organisasi sosial. Dengan sendirinya hal tersebut memudahkan dan mendorong konseptualiasasi ilmu sosial dan bantuan konseptual teori Weber tentang birokrasi adalah terletak pada penjelasan ketika dia mendiskusikan tipe rasional yang murni.

Dalam sejarahnya, patologi birokrasi (Bureaupathology) dikenal sejak hadirnya rutinitas kegiatan yang menyibukkan para birokrat itu sendiri dan menciptakan aktifitas yang berbelit-belit. Kemudian kondisi ini dikenal dengan istilah Red Tape (pita merah) Yakni birokrasi yang berbelit-belit sehingga menciptakan perilaku birokrasi yang sangat bertentangan dengan tujuan mulia kehadiran birokrasi itu sendiri di tengah-tengah masyarakat. Kajian dan eksprimen terhadap patologi birokrasi pun kian berkembang dan menghasilkan banyak pandangan atau teori tentang patologi birokrasi. pada kenyataannya negara berkembang telah menjadi 'ruang dan tempat' tumbuh suburnya patologi birokrasi. Seperti Indonesia sebagai negara berkembang masih dalam selimut patologi birokrasi, mulai 
dari birokrasi pusat hingga birokrasi di daerah. Bahwa ternyata desentralisasi atau otonomi daerah yang sedang dan terus dijalani bangsa ini belum mampu menyingkirkan patologi birokrasi, bahkan di beberapa daerah kita menyaksikan semakin mengukuhkan patologi birokrasi itu sendiri. Ciri ini dapat kita lihat, pertama betapa administrasi publik kita masih kerap bersifat elitis, otoriter, paternalistik, serta menjauh dari masyarakat dan lingkungannya. Bahwa keberadaan birokrasi belum menyatu dalam kehidupan masyarakat dan belum mengakomodir kolektifitas atau partisipasi semua unsur dalam agenda birokrasi. Kedua, birokrasi kita kekurangan sumber daya manusia (dalam hal kualitas) untuk menyelenggarakan pembangunan dan over (berlebih) dalam segi kuantitas.

Fakta ini telah kita saksikan, birokrasi kita masih saja lemah secara sumber daya manusia dan sangat wajar lemah, karena dalam proses rekrutmennya selama ini bukan atas dasar kualitas, dan inilah salah satu produk patologi birokrasi tersebut. Secara kuantitas, jelas birokrasi Indonesia sangat gemuk dan over lembaga dalam menangani sektor-sektor yang pada dasarnya sama. Sehingga sering kita menyaksikan di kantor-kantor pemerintahan kita banyak aparatur yang tidak bekerja dan terjadinya tumpang tindih dalam penanganan masalah dalam memberikan pelayanan publik. Ketiga, birokrasi kita masih lebih berorientasi kepada kemanfaatan pribadi ketimbang kepentingan masyarakat. Telah menjadi sebuah realitas yang berkepanjangan bahwa mental dan kultur birokrasi kita masih berazas manfaat pribadi atau kelompok serta sangat pragmatis dan mengabaikan kehendak rakyat.

Kenyataan ini dekat dengan kita, di mana para birokrat kita begitu kaya-kaya atau sejahtera secara materiil secara tidak layak bila dibandingkan gaji yang ditetapkan. keempat, birokrasi kita sering mengutamakan formalitas daripada substansi. Bahwa banyak penyelenggaraan birokrasi kita dalam melaksanakan pembangunan hanya bersifat sekedar tanpa mengoptimalkan sisi esensi, manfaat dan dampak positif nya jauh ke depan. Serta sering bersifat ceremonial. Kelima, birokrasi kita masih asik dengan jalannya sendiri tanpa memperhitungkan atau mengakomodir aspirasi rakyat. Birokrasi kita, khususnya di daerah, masih jauh dari pengawasan yang seyogianya. Artinya, lepas dari proses politik dan pengawasan publik secara kuat.

Menurut Mathis \& Jackson (2001:102), competency is a base characteristic that correlation of individual and team performance acheivement. Kompetensi adalah karakteristik dasar yang dapat dihubungkan dengan peningkatan kinerja individu atau tim. Pengelompokan kompetensi terdiri dari pengetahuan (knowledge), keterampilan (skill), dan kemampuan (abilities).

Berdasarkan UU No. 13/2003 tentang Ketenagakerjaan: pasal 1 ( 10 ) "Kompetensi adalah kemampuan kerja setiap individu yang mencakup aspek pengetahuan, keterampilan dan sikap kerja yang sesuai dengan standar yang ditetapkan."

Menurut Watson Wyatt dalam Ruky (2003:106) competency merupakan kombinasi dari keterampilan (skill), pengetahuan (knowledge), dan perilaku (attitude) yang dapat diamati dan diterapkan secara kritis untuk suksesnya sebuah organisasi dan prestasi kerja serta kontribusi pribadi karyawan terhadap organisasinya.

Pengetahuan adalah hasil dari tingkah laku dan ini terjadi setelah seseorang melakukan suatu pengindraan terhadap suatu objek tertentu. Pengindraan terjadi melalui panca indra manusia yaitu indra penglihatan, penciuman, rasa, raba, dan pengucapan. Sebagian besar pengetahuan manusia diperoleh melalui mata dan telinga (Soekidjo Notoatmodjo, 2002: 3). Pengetahuan adalah segala sesuatu yang diketahui; kepandaian (Kamus Besar Bahasa Indonesia , 2003). (Menurut Notoatmodjo , 2003 :6) Pengetahuan adalah hasil dari tahu dan terjadi setelah orang melakukan penginderaan terhadap objek tertentu. Penginderaan terjadi melalui panca indera manusia yaitu indera penglihatan, pendengaran, penciuman, rasa dan raba. Sebagian besar pengetahuan manusia diperoleh melalui mata dan telinga.

Berdasarkan Peraturan Pemerintah Republik Indonesia Nomor 101 Tahun 2000 tentang Pendidikan dan Pelatihan Jabatan Pegawai Negeri Sipil, pendidikan dan pelatihan merupakan 
proses penyelenggaraan pemerintah dalam rangka meningkatkan kemampuan Pegawai Negeri Sipil. yang bertujuan untuk meningkatkan pengetahuan, keahlian, keterampilan, dan sikap untuk dapat melaksanakan tugas jabatan secara profesional dengan dilandasi kepribadian dan etika PNS sesuai dengan kebutuhan instansi. Dengan demikian kebijaksanaan peningkatan kinerja pegawai apakah melalui pendidikan dan pelatihan sekaligus juga merupakan upaya peningkatan sumber daya pegawai secara rasional. Hal ini berarti pula bahwa pendidikan dan pelatihan pegawai merupakan hal yang mutlak untuk dilaksanakan secara sistematis dan berkesinambungan karena sudah merupakan kebutuhan yang nyata bagi sumber daya aparatur.

Peraturan Menteri Pendayagunaan Aparatur Negara tentang Jabatan Fungsional widyaiswara nomor 66 tahun 2005, Pendidikan adalah segala usaha yang bertujuan mengembangkan sikap dan kepribadian, pengetahuan dan keterampilan. Pelatihan adalah proses pembelajaran yang lebih menekankan pada praktek dari pada teori yang dilakukan seseorang atau kelompok dengan menggunakan pendekatan pelatihan untuk orang dewasa dan bertujuan meningkatkan kemampuan dalam satu atau beberapa jenis keterampilan tertentu. Pendidikan dan Pelatihan Jabatan Pegawai Negeri Sipil yang selanjutnya disebut diklat PNS adalah proses penyelenggaraan pemerintah dalam rangka meningkatkan kemampuan Pegawai Negeri Sipil.

Menyadari betapa pentingnya peranan sumber daya manusia aparatur dalam hal ini adalah Pegawai Negeri Sipil dalam pembangunan, maka para pegawai perlu diberdayakan secara optimal lagi. Hal ini akan dicapai apabila pengetahuan dan tanggung jawab dalam pelaksanaan tugas-tugas pemerintahan maupun pembangunan yang diemban oleh para Pegawai Negeri Sipil dapat dilaksanakan secara maksimal. Dalam rangka inilah diperlukan upaya pembinaan baik dalam karier maupun prestasi kerja Pegawai Negeri Sipil yang bersangkutan.

Pada umumnya, metode pelatihan dikenal melalui jalan on-the job training, belajar sendiri, pelatihan yang diselenggarakan oleh organisasi sendiri, seminar, lokakarya atau dengan mengundang konsultan pelatihan dari luar organisasi ( Syuhadhak, 1994:62 ). Hal ini berarti terdapat upaya internal organisasi untuk meningkatkan kapabilitasnya dalam berbagai bentuk.

Pelatihan melalui on-the job training dilakukan setiap hari dengan menjawab pertanyaan, mendemonstrasikan bagaimana pekerjaan dilakukan dan memberikan pedoman kerja. Pelatihan dengan belajar sendiri dilakukan dengan menyediakan buku petunjuk terinci. Selanjutnya dalam organisasi sendiri dapat ditempuh melalui lokakarya atau pelatihan biasa. Harus dapat diupayakan memilih orang untuk mengikuti pelatihan dan penataran yang sesuai dan harus diyakini bahwa setelah pelatihan pengetahuan dan kemampuannya akan bertambah serta hasil kerjanya dapat meningkat.

Dari pandangan tersebut, bisa dinyatakan bahwa upaya peningkatan kualitas kinerja pegawai melalui pendidikan dan pelatihan dapat menciptakan pelaksanaan tugas yang lebih baik serta menciptakan efektifitas pencapaian sasaran tugas yang ditentukan bagi setiap bagian dalam organisasi. Dalam sisi lain, konsultan pelatihan yang tersedia dalam masyarakat biasanya menyediakan berbagai paket pelatihan yang dapat disesuaikan dengan kebutuhan organisasi. Hal ini diupayakan dengan harapan adanya dinamisasi pelaksanaan pendidikan dan pelatihan yang lebih bersifat mengenal lingkungan internal masing-masing dan lingkungan eksternal dalam pelaksanaan tugas yang dibebankan organisasi.

Reinventing Goverment lahir pada puncak kejenuhan terhadap pola "Big Goverment" Clinton menyatakan bahwa masa organisasi hirarki telah lewat, sekarang sudah masanya small and effective organization. Bennis dalam Thoha (2003:3) meramalkan bahwa birokrasi weber sekitar 25-50 tahun yang akan datang (terhitung mulai tahun 1967) kita bersamasama akan menyaksikan jatuhnya birokrasi Weber dan digantikan dengan sistem sosial yang baru sesuai dengan kondisi masyarakat.

Gagasan Reinventing Goverment mengglobal keberbagai belahan dunia tradisional 
yang hanya mulai dari Amerika Serikat, Selandia Baru, Inggris dan Australia serta Indonesia. Pemerintah wirausaha bersedia meninggalkan program dan metode lama. Ia bersifat inovatif, imajinatif, dan kreatif, serta berani mengambil risiko. Ia juga mengubah beberapa fungsi kota menjadi sarana penghasil uang ketimbang penguras anggaran, menjauhkan diri dari alternatif tradisional yang hanya memberikan sistem penopang hidup. Ia bekerja sama dengan sektor swasta, menggunakan pengertian bisnis yang mendalam, menswastakan diri, mendirikan berbagai perusahaan dan mengadakan berbagai usaha yang menghasilkan laba. Ia berorientasi pasar, memusatkan pada ukuran kinerja, memberi penghargaan terhadap jasa.

Upaya meningkatkan produktifitas kerja dan mutu pelayanan yang diberikan oleh para anggota birokrasi pemerintahan kepada masyarakat harus pula dikaitkan dengan pengetahuan dan keterampilan para anggota birokrasi tersebut. Artinya, rendahnya produktifitas kerja dan mutu pelayanan tidak semata-mata disebabkan oleh tindakan dan prilaku yang disfungsional akan tetapi sangat mungkin karena tingkat pengetahuan dan keterampilan tidak sesuai dengan tuntutan tugas yang diemban anggota birokrasi.

Pada gilirannya, tingkat pengetahuan dan keterampilan yang rendah berkaitan pula dengan berbagai aspek manajemen sumber daya manusia dalam birokrasi yang bersangkutan. Misalnya, apabila proses rekruitmen dan seleksi tidak dilakukan dengan baik, akibatnya ialah bahwa yang diterima menjadi pegawai bukanlah tenaga-tenaga yang memiliki pengetahuan dan keterampilan tinggi sesuai dengan tuntutan tugasnya. Segi lain ialah, penempatan yang tidak didasarkan pada pertimbangan-pertimbangan objektif dan rasional, seperti latar belakang pendidikan, pelatihan yang pernah diikuti, pengalaman, minat dan bakat pegawai. Salah satu akibatnya adalah potensi yang terdapat dalam diri pegawai tidak dikembangkan dan tidak pula dimanfaatkan sebagaiman mestinya.

\section{METODE PENELITIAN}

Penelitian dilakukan di wilayah kabupaten Bantaeng di Sekretariat Daerah Kabupaten Bantaeng Tipe Penelitian bersifat deskriptif kualitatif yang dikombinasi dengan data kuantitatif dan Dasar penelitian yang dilakukan adalah survey yaitu penelitian dengan mengumpulkan dan menganalisis suatu peristiwa atau proses tertentu dengan memilih data atau menemukan ruang lingkup tertentu sebagai sampel yang dianggap representatif. Populasi dalam penelitian ini adalah Pegawai Negeri Sipil yang terdapat dalam lingkup Sekretariat Pemerintah Kabupaten Bantaengdan Teknik penarikan sampel yang digunakan dalam penelitian ini adalah sample total yaitu mengambil sampel secara subjektif yang dianggap representative. Dalam penelitian ini data-data yang diambil dapat digolongkan menjadi dua bagian yaitu data sekunder dan data primer. Data sekunder adalah data yang bersumber dari kepustakaan (library Study), sedangkan data primer adalah data yang bersumber dari studi lapang (Field Research). Studi lapang yang dilakukan dengan tujuan untuk memperoleh data-data yang akurat mengenai obyek yang diteliti dengan menggunakan teknik Observasi,Wawancara dan Kuesioner. Jenis Data dalam penelitian ini adalah Kualitatif yaitu data-data yang tidak berbentuk angka, tetapi cukup menggambarkan suatu keadaan yang berhubungan dengan patologi birokrasi pemerintahan daerah (studi kasus masalah pengetahuan dan keterampilan aparatur di sekretariat kabupaten Bantaeng). Dan data kuantitatif yaitu data yang diperoleh dari jawaban responden dalam bentuk angka-angka.Sumber data yang diperoleh dalam penelitian ini berasal dari data primer dan sekunder. teknik analisis data yang penulis gunakan dalam mengelola data adalah teknis analisis deskiptif kuantitatif dari data hasil observasi, wawancara dan kuesioner setelah data dikumpulkan selanjutnya dianalisis data melalui tabel frekwensi.

\section{HASIL PENELITIAN DAN PEMBAHASAN}

PENGETAHUAN DAN KETERAMPILAN
PEGAWAI DI SEKRETARIAT DAERAH
KABUPATEN BANTAENG


Sebagaimana yang dijelaskan pada kerangka konseptual bahwa upaya meningkatkan produktifitas kerja dan mutu pelayanan yang diberikan oleh para anggota birokrasi pemerintahan kepada masyarakat harus pula dikaitkan dengan pengetahuan dan keterampilan para anggota birokrasi tersebut. Artinya, rendahnya produktifitas kerja dan mutu pelayanan tidak semata-mata disebabkan oleh tindakan dan prilaku yang disfungsional akan tetapi sangat mungkin karena tingkat pengetahuan dan keterampilan tidak sesuai dengan tuntutan tugas yang diemban anggota birokrasi.

Pada gilirannya, tingkat pengetahuan dan keterampilan yang rendah berkaitan pula dengan berbagai aspek manajemen sumber daya manusia dalam birokrasi yang bersangkutan. Misalnya, apabila proses rekruitmen dan seleksi tidak dilakukan dengan baik, akibatnya ialah bahwa yang diterima menjadi pegawai bukanlah tenaga-tenaga yang memiliki pengetahuan dan keterampilan tinggi sesuai dengan tuntutan tugasnya. Segi lain ialah, penempatan yang tidak didasarkan pada pertimbangan-pertimbangan objektif dan rasional, seperti latar belakang pendidikan, pelatihan yang pernah diikuti, pengalaman, minat dan bakat pegawai. Salah satu akibatnya adalah potensi yang terdapat dalam diri pegawai tidak dikembangkan dan tidak pula dimanfaatkan sebagaiman mestinya.

Masalah pengetahuan dan keterampilan menjadi semakin rumit, apabila dalam birokrasi tidak terdapat program pendidikan dan pelatihan yang betul-betul dikaitkan dengan tuntutan tugas dan tantangan yang diperkirakan akan dihadapi oleh birokrasi. Dalam hal demikian, produktifitas kerja dan mutu pelayanan akan menjadi rendah karena para pegawai sering melakukan kesalahan.

\section{Tingkat Pendidikan}

Pendidikan merupakan salah satu dari beberapa faktor yang berada dalam diri setiap manusia yang di dapat dari proses pembelajaran. Kebutuhan akan pendidikan terutama bagi aparat pemerintah adalah sesuatu yang mutlak. Kecakapan, pengetahuan, dan keterampilan yang diperoleh melalui pendidikan formal dan pendidikan non ormal, sehingga mampu mendorong dan mengembangkan kecerdasan seseorang dalam memahami fenomena-fenomena yang timbul sesuai bakat dan karakter.

Pendidikan pegawai sangat perlu untuk diperhatikan agar prinsip the right man on the right please dapat diterapkan dalam kehidupan suatu organisasinya pada umumnya para pegawai tentunya mengharapkan agar mereka ditemptkan sesuai dengan jenis dan tingkat pendidikan yang diikutinya.

Peningkatan kualitas sumber daya manusia dapat dicapai melalui latihan dan pendidikan, serta penguasaan ilmu pengetahuan dan teknologi melalui bangku pendidikan. Oleh karena itu pendidikan sebagai sarana untuk meningkatkan kualitas manusia, termasuk bagi aparat pemerintah dalam melaksanakan fungsinya sebagai pelayan masyarakat dan dalam melaksanakan tugas-tugas pokoknya. Namun dalam upaya untuk menambah pengetahuan dan wawasan tidak hanya pendidikan formal saja yang dibutuhkan, akan tetapi pendidikan non formal yang relevan dengan bidang tugas yang akan digelutinya juga sangat diperlukan.

Berdasarkan hasil wawancara dengan informan yaitu staf di kabag pemerintahan:

"Sesuai dengan latar belakang pendidikan pegawai disekretariat daerah di kabupaten bantaeng masih tergolong rendah itu bisa dilihat dari pendidikan formal pegawai di secretariat daerah kabupaten bantaeng. Apabila tingkat pendidikan yang rendah sangat menberikan pengaruh negative sebab kurangnya pengetahuan tentang tugas kerjanya" (wawancara,NS, 9 Oktober 2012).

Berdasarkan hasil observasi peneliti kenyataan yang dilihat di lapangan masih banyak pegawai yang tingkat pendidikannya rendah, kemudian masih banyak yang tidak sesuai dengan job decription atau masih banyak pegawai yaqng tidak sesuai dengan tuntutan tugas yang diembannya semua hanya karena faktor kedekatan dengan pimpinan.

Hasil wawancara yang diperoleh dari informan yaitu kabag umum : 
"Pegawai di sekretariat daerah kabupaten bantaeng sudah dapat dikategorikan cukup baik dilihat dari penempatannya dengan latar belakang pendidikannya". (wawancara, AN, 9 OKTOBER 2012).

Berdasarkan hasil observasi peneliti masih banyak dikantor di setda Bantaeng yang penempatannya tidak sesuai dengan latar belakang pendidikannya. Seharusnya pegawai setda menerapkan prinsip the right man on the right please yaitu mengharapkan agar mereka ditempatkan sesuai dengan jenis dan tingkat pendidikan yang diikutinya

Tingkat pendidikan formal yang dimiliki oleh seorang Pegawai Negeri Sipil mempengaruhi di dalam memahami pelaksanaan dari tugas-tugas pokok yang dijalankannya. Oleh karena itu sebahagian besar pegawai yang ada di Sekretariat Kabupaten Bantaeng yang memiliki pendidikan formal yang memadai, dengan mudah memahami setiap pekerjaan atau tugas-tugas yang akan dilaksanakan, sehingga pengaruh pendidikan formal dalam melaksanakan tugas sangat dirasakan.

Berbeda dengan para Pegawai Negeri Sipil yang memiliki tingkat pendidikan Formal yang kurang memadai, dimana di dalam melaksanakan pekerjaan dan tugas-tugasnya masih kurang memahami sehingga dalam pelaksanaannya kadangkala tidak sesuai dengan apa yang diinginkan atau tujuan dari pekerjaannya masih belum bisa tercapai. Oleh karena itu seorang pegawai tidak hanya dituntut untuk meningkatkan pengetahuannya melalui pendidikan formal saja, akan tetapi untuk dapat meningkatkan ketrampilan dan wawasan yang lebih baik diperlukan juga pendidikanpendidikan dan pelatihan-pelatihan terutama yang berkaitan langsung dengan pekerjaan dan pelaksanaan tugas-tugas pokoknya.

Jarangnya Aparat Pemerintah mengikuti pendidikan non formal disebabkan karena para Aparat Pemerintah sendiri kurang membuat suatu program kegiatan untuk meningkatkan sumber daya Aparat Pemerintah berupa kursus-kursus singkat yang berkaitan dengan tugas-tugasnya sehari-hari. Walaupun demikian tidak berarti para Aparat Pemerintah tidak seorangpun pernah mengikuti kursus atau pelatihan, namun kursus atau pelatihan yang pernah diikuti oleh Aparat Pemerintah sangat terbatas pesertanya yang datang atau diundang, oleh karena penyelenggaranya hanya kerabat dekatnya saja, sehingga sangat sedikit para Aparat Pemerintah yang memperoleh kesempatan untuk menambah pengetahuan, ketrampilan dan wawasannya dalam rangka pelaksanaan tugas dan fungsi yang diembannya.

Pendidikan non formal juga membawa pengaruh dalam melaksanakan tugas dan fungsinya sebagai pelayan masyarakat, sehingga persepsi yang dibangun sesama para Aparat Pemerintah dapat diimplementasikan dalam bentuk perubahan birokrasi yang lebih baik bukan pada bentuk timbulnya inkonsistensi birokrasi berupa munculnya penyakitpenyakit birokrasi.

Pengaruh pendidikan non formal dalam melaksanakan tugas-tugas pokoknya dirasakan oleh para aparat pemerintah masih kurang berpengaruh. Hal ini disebabkan oleh karena jarangnya mereka mengikuti pendidikan den pelatihan yang langsung berhubungan dengan pelaksanaan tugas pokok dan fungsinya, sehingga pelaksanaan tugas dan fungsinya terutama dalam hal tugas-tugas pokok aparat diinterprestasikan secara berbeda-beda menurut pemahamannya masing-masing, sehingga sasaran yang ingin dicapai masih jauh dari harapan yang dikehendaki.

Munculnya perbedaan dalam mempersepsikan suatu permasalahan di dalam pelaksanaan tugasnya terlihat dari pola tugas-tugas pokok yang dikerjakan dengan hasil yang telah ada. Dengan demikian pelaksanaan pendidikan non formal yang berkenaan dengan pelaksanaan tugas dan fungsinya mutlak diperlukan dalam rangka meningkatkan kinerja aparat pemerintah, sehingga akan diperoleh hasil yang maksimal. Namun jika hal ini belum pula dilakukan maka akan tetap menjadi sebuah penyakit.

\section{Pelatihan}

Pendidikan dan Latihan Teknis adalah pendidikan dan latihan yang diselenggarakan untuk memberikan keterampilan dan penguasaan pengetahuan bidang teknis tertentu kepada Pegawai Negeri Sipil sehingga mampu 
mekksanakan tugas dan tanggung jawab yang diberikan dengan sebaik-baiknya.

Pelatihan diberikan kepada pegawai dengan upaya peningkatan keterampilannya. Pelatihan adalah serangkaian aktivitas yang dirancang untuk meningkatkan keahliankeahlian, pengetahuan, pengalaman, ataupun perubahan sikap seorang individu. Untuk mengukur kualitas sumber daya aparatur di Sekretariat Daerah Kabupaten Bantaeng adalah keikutsertaan pegawai met.gikuti pelatihan untuk meningkatkan keterampilan. Dengan mengikuti pelatihan diharapkan pard aparatur mampu meningkatkan keterampilannya guna menunjang aparatur dalam melaksanakan tugasnya. Hal ini dapat diliat dari tabel dibawah ini:

Tabel 1

Pelatihan yang pernah dikuti aparat pemerintah

\begin{tabular}{|l|l|c|c|}
\hline No. & Pendidikan \& Pelatihan & Frekuensi & Presentase \\
\hline 1 & Diklat Sispanas & - & \\
\hline 2 & Diklat Spamen/Diklatpim Tk II & 1 & $10 \%$ \\
\hline 3 & Diklat Sparna/Diklatpim Tk III & 4 & $40 \%$ \\
\hline 4 & Diklat Adum/Adumla & 2 & $20 \%$ \\
\hline 5 & Diklat Manajemen Proyek & - & - \\
\hline 6 & Diklat Bendaharawan & 3 & $30 \%$ \\
\hline 7 & Diklat Lainnya & - & - \\
\hline & JUMLAH & 10 & $100 \%$ \\
\hline
\end{tabular}

Sumber : Sekretariat Daerah Kabupaten Banlaeng 2012

Yang telah digambarkan pada tabel di atas, maka dapat ditarik kesimpulan bahwa dari 36 responden terdapat $18(50 \%)$ responden yang telah mengikuti pelatihan teknis walaupun minimal diklat prajabatan telapi diharapkan mampu meningkatkan pengetahuan dan keterampilan aparat sesuai dengan tujuan diklat prajabatan yaitu memberikan pengetahuan dalam rangka pembentukan wawasan kebangsaan, kepribadian dan etika Pegawai Negeri Sipil, disamping pengetahuan dasar tentang sistem penyelenggaraan pemerintahan negara, bidang tugas dan budaya organisasinya, agar mampu melaksanakan lugas dan perannya sebagai pelayan masyarakat, dan diharapkan lugi untuk mereka dapat melanjutkan ke jenjang dan pelatihan yang lebih tinggi. Namun, bila di perhatikan dari tabel 14 separuh dari keseluruhan responden hanya mengikuti diklat 1 atau 2 kali jupun pada saat prajabatan. Hal tersebut perlu dicermati lagi oleh Pemerintah kabupaten Bantaeng unluk segera diupayakan peningkatan kuantitas pelaksanaan pendidikan pelatihan aparat yang idealnya dilakukan secara simultan dan berkesinambungan.

Hasil ubservasi peneliti masih ditemukan adanya pegawai struktural yang tidak mengikuti diklat, sebagaimana yang telh dicantumkan pada tabel diatas. Berdasarkan dari hasil wawancara salah satu dari pejabat struktural sebelum menjabat kabag humas dia menjabat sebagai salah satu staf di PU.

Dengan adanya gambaran di atas, dimungkinkan bahwa dengan mengikuti pendidikan dan latihan akan membuat aparat semakin mengerti dengan pekerjaan yang diberikan, selain itu aparat juga semakin terdidik dan disiplin dalam menyelesaikan tugas-tugasnya. Sulssesnya pendidikan dan latihan ini diukur dengar hasil kerjakeras para aparatyang telah mengikuti pendidikan dan latihan kerja.

Perlu diketahui bahwa Pendidikan dan Latihan Teknis memiliki manfaat yang begitu besar bagi aparat dalam meklksanakan tugastugas yang bersifat teknis di lapangan. Apabila aparat menguasai berbagai pengetahuan yang berhubungan persoalan teknis di lapangan maka akan membuat aparat lebih profesional dalam mekaksanakan tugasnya.

Berhasil tidaknya Pendidikan dan Latihan Teknis dapat diukur dari sejauh mana Pendidikan dan Latihan Teknis tersebut mempengaruhi pelaksanaan tugas-tugas pokok dari aparat yang bersangkutan dan dapat bermanfaat bagi pengembangan kualitas dan kemampuannya terutama yang mengenai hal-hal yang bersifat teknis.

Bersangkutan, lebih-lebih apabila pengetahuan dan teknologi makin berkembang dengan pesatnya. Pada dasarnya pendidikan dan pelatihan itu merupakan proses yang berlanjut dan bukan proses sesaat saja. Munculnya kond'si-kondisi baru sangat mendorong pimpinan organisasi pendidikan yang continue serta semantap mungkin.

Pendidikan dan pelatihan merupakan kegiatan pengembangan sumber daya manusia untuk meningkatkan kemampuan pegawai 
atau aparatur di luar kemampuan di bidang pekerjaan atau jabatan yang dipegang, sebab pendidikan pegawai dirancang atau disesuaikan dengan posisi baru, dimana tugastugas dilakukan memerlukan kemampuankemampuan khusus yang lain dari yang mereka miliki sebelumnya, dengan demikian tujuan pendidikan pegawai yakni untuk mempersiapkan pegawai dalam menempati posisi atau jabatan baru, terutama dalam bidang pengelolaan kepegawaian yang professional. Uraian tersebut menjelaskan bahwa betapa pentingnya peran pegawai atau aparatur sebagai sumber daya manusia dalam upaya mendukung keberhasilan organisasi. Namun masalahnya yang paling mendasar adalah masih lemahnya sumber daya manusia yang mampu mengelola pembangunan berbagai sektor berdasarkan kebutuhan sosial, ekonomi, dan budaya masyarakat apalagi dibawah tekanan persaingan ekonomi global.

Demikian halnya Kantor Sekretariat Daerah Kabupaten Bantaeng sebagai suatu organisasi yang merupakan bagian dari pelaksaan pembangunan di Kabupaten Bantaeng dituntut untuk meningkatkan aparaturnya dalam menunjang pelaksanaan pembangunan di Kabupaten Bantaeng Karena tidak menutup kemungkinan bahwa dalam lingkup Kantor Sekretariat Daerah Kabupaten Bantaeng juga memiliki hambatan-hambatan dalam penyelenggaraan organisasi yang tidak lain disebabkan oleh karena kualitas sumber daya manusianya yang tidak mendukung. Jika hal demikian terjadi maka sulit bagi organisasi tersebut mencapai visi dan misinya. Kantor Sekretariat daerah Kabuapten Bantaeng perlu untuk senantiasa memperhatikan pengemba-ngan aparaturnya secara keseluruhan yang dapat dilaksanakan melalui pelaksanaan pendidikan dan pelatihan untuk peningkatan pengetahuan, keterampilan, dan kemampuan mereka. Sehingga aparatur pemerintah dalam lingkup kantor tersebut seyogyanya dapat melaksanakan tugastugas dan kegiatan-kegiatan dengan baik dalam usaha yang bersangkutan demi menacapai tujuan yang telah di tetapkan sebelumnya.

Kenyataaan yang terjadi bahwa kualitas sumber daya manusia khususnya pegawai Sekretariat Daerah Bantaeng belum maksimal.
Hal ini di tandai dengan kurangnya disiplin kerja, masih kurang tingkat pendidikan, dan terdapat pegawai yang latar belakang pendidikan yang tidak sesuai dengan pekerjaan yang diembannya. Dilihat dari hasil observasi sebelumnya, jabatan yang diduduki oleh Pegawai Negeri Sipil tidak selamanya berdasarkan latar belakang pendidikan dan kompetensi yang dimiliki, misalnya fakta yang di temukan dilapangan bahwa ada lulusan teknik mesin yang bekerja di bidang administrasi dan masih banyak pegawai yang kurang mampu menyelesaikan tugas yang diembannya dengan baik karena kurangnya pengetahuan dan keterampilan yang dimiliki. Hal ini tentu saja berpengaruh terhadap kualitas kerja mereka karena dalam hal ini mereka tidak menguasai betul bidang pekerjaan yang digelutinya.

\section{Pengalaman}

Pendapat Stephen p.robbins (1996:218) bahwa tingkat kinerja pegawai akan sangat bergantung pada faktor kemampuan pegawai itu sendiri seperti tingkat pendidikan, pengetahuan, pengalaman dimana dengan kemampuan yang semakin tinggi akan mempunyai kinerja semakin tinggi pula. Pengalaman menjadi salah satu faktor kemampuan pegawai yang sangat penting dan berpengaruh terhadap kinerja pegawai.

Masa kerja, sebagian besar pegawai di Sekretariat daerah kabupaten Bantaeng memiliki pengalaman kerja yang pendek.Masa kerja PNS sangat mempengaruhi kematangan di dalam bekerja yang berimplikasi pada wawasan dan kematangan dalam bersikap, sehingga diharapkan dengan kematangan yang dimiliki mampu menjalankan tugastugas pokoknya atau yang telah diberikan kepadanya sehingga dalam memandang setiap permasalahan yang terjadi di dalam pekerjaannya dituangkan dalam bentuk kematangan bersikap bagaimana caranya dia menyelesaikan masalah yang dihadapi tanpa harus menghambat pekerjaannya yang lain atau meminta petunjuk kepada atasan.

\section{Pemahaman pekerjaan}

Berhubungan dengan profesionalisme aparat, maka pemahaman pekerjaan dalam 
pelaksanaan tugas-tugas dari aparat pemerintahan sangatlah penting dimana adanya ketepatan waktu, ketetapan sasaran dan dengan biaya yang seminimal mungkin serta adanya keseriusan dalam melaksanakan tugas. Hal dikarenakan karena keberhasilan tugas dan fungsi aparat sangat berguna dalam pelaksanaan Otonomi Daerah.

Hasil pengamatan langsung di lapangan memperlihatkan bahwa banyak aparat yang tidak disiplin terhadap waktu. Banyak aparat yang masih terlambat datang ke kantor, tidak mengikuti apel pagi karena terlambat tiba di kantor atau tidak mengikuti apel sore karena pulang lebih awal. Ada juga yang hanya datang mengisi daftar hadir lalu pergi dan tidak kembali lagi ke tempat kerja atau bolos kerja. Bahkan dari hasil pengamatan lainnya yaitu ketika ada hari kerja yang terjepit dengan harihari libur pada awal atau akhir pekan. Pada situasi dan kondisi seperti ini masih ada sebagian aparat yang membolos.

\section{Analisis Pekerjaan}

Analisis pekerjaan sangat penting dilakukan oleh aparat pemerintahan.ada beberapa manfaat yang diperoleh dengan mengadakan analisis pekerjaan, yang juga merupakan tujuan dari dilakukannya analisis jabatan. hasil-hasil dari analisis pekerjaan seperti uraian dan spesifikasi pekerjaan akan dapat digunakan untuk kegiatan-kegiatan seperti pelatihan dan evaluasi pekerjaan. berikut ini tanggapan responden dalam menganalisis suatu pekerjaan sebagai aparat pemerintahan. Indikator untuk mengukur kualitas sumber daya aparatur dalam menganalisis suatu pekerjaan di Sekretariat Daerah Kabupaten Bantaeng adalah kemampuan untuk menjalankan tugas. Kemampuan sangat diperlukan oleh pegawai untuk menjalankan tugas, karena dengan hal tersebut para pegawai akan lebih mudah dalam menjalankan tugas tugasnya.

\section{UPAYA YANG DILAKUKAN DALAM MASALAH PENGETAHUAN DAN KETERAMPILAN DI SEKRETARIAT DAERAH KABUPATEN BANTAENG}

Solusi yang ditawarkan untuk mengatasi Patologi Birokrasi yaitu: Yang pertama, perlu adanya reformasi administrasi yang global. Artinya reformasi administrasi bukan hanya sekedar mengganti personil saja, bukan hanya merubah nama intansi tertentu saja, atau bukan hanya mengurangi atau merampingkan birokrasi saja namun juga reformasi yang tidak kasat mata seperti upgrading kualitas birokrat, perbaikan moral, dan merubah cara pandang birokrat, bahwa birokrasi merupakan suatu alat pelayanan publik dan bukan untuk mencari keuntungan.

Menciptakan sistem akuntabilitas dan transparansi. Kurangnya demokrasi dan rasa ber-tanggung jawab yang ada dalam birokrasi membuat para birokrat semakin mudah untuk menyeleweng dari hal yang semstinya dilakukan. Pengawasan dari bawah dan dari atas merupakan alat dari penciptaan akuntabilitas dan transparansi ini. Pembentukan E-Government diharapkan mampu menambah transparansi sehingga mampu memperkuat akuntabilitas para birokrat.

Untuk mewujudkan suatu birokrasi pemerintahan yang baik, selain dilihat dari aparat birokrasi pemerintahannya sebagai pelaksana jalannya suatu birokrasi juga diperlukan suatu kekuatan-kekuatan politik atau organisasi massa sebagai pengontrol jalannya birokrasi. Selain itu dalam melaksanakan pelayanan umum di Sekretariat Daerah Kabupaten Bantaeng, baik itu pelayanan perizinan, pembuatan dokumen, perlindungan, pemeliharaan fasilitas umum, pemeliharaan kesehatan dan penyediaan jaminan keamanan bagi penduduk dari segala aspek kehidupan masyarakat, pemerintah senantiasa melayani dengan berorientasi pada prinsip-prinsip Good Governance.

\section{E. KESIMPULAN}

Aparat di Sekretariat kabupaten Bantaeng telah menimbulkan suatu patologi birokrasi pada organisasi pemerintahan ini, yaitu mengenai tingkat pendidikan yang rendah, dimana sebagian besar Aparat Pemerintah tidak pernah mengikuti pendidikan non formal yang berbentuk kursus atau pelatihan, dimana seharusnya bagi Aparat Pemerintah lebih banyak diberikan pendidikan-pendidikan non 
formal, sehingga sangat mempengaruhi kinerja dari Aparat Pemerintah itu sendiri, serta dalam pemahaman pekerjaan sebagian besar aparat tidak mengerjakan tugasnya dengan alasan tidak paham dengan tugas tersebut.

Faktor-faktor yang menimbulkan patologi birokrasi pemerintahan daerah dan upaya yang dilakukan dalam masalah pengetahuan dan keterampilan aparatur di Sekretariat Daerah Kabupaten Bantaeng.

1. Faktor-faktor yang menimbulkan patologi birokrasi pemerintahan daerah: tidak ada pegawai yang betul-betul tidak kompeten dalam segala hal, seseorang dapat menampilkan inkompetensi apabila penempatannya tidak tepat, penempatan yang tidak tepat merupakan akibat tidak sesuainya tugas pekerjaan seseorang dengan latar belakang pendidikannya, keterampilan khusus yang dimilinya, bakat serta minatnya, kepribadiannya, konfigurasi fisik dan mentalnya.

2. Upaya Yang Dilakukan Dalam Masalah pengetahuan dan keterampilan di Sekretariat Daerah Kabupaten Bantaeng yaitu perlu adanya reformasi administrasi yang global. Artinya reformasi administrasi bukan hanya sekedar mengganti personil saja, bukan hanya merubah nama intansi tertentu saja, atau bukan hanya mengurangi atau merampingkan birokrasi saja namun juga reformasi yang tidak kasat mata seperti upgrading kualitas birokrat, perbaikan moral, dan merubah cara pandang birokrat, bahwa birokrasi merupakan suatu alat pelayanan publik dan bukan untuk mencari keuntungan.

\section{DAFTAR PUSTAKA}

Albrow, Martin, 1989, Birokrasi, Yogyakarta : Tiara Wacana,

Alfian dan Nasaruddin Syamsuddin, 1991, Profil Budaya Politik Indonesia, Jakarta: Pustaka Utama, Grafiti.
Amirin Tatang, 1985, Menyusun Rencana Penelitian, Raja Grafindo Persada, Jakarta.

Blau, Peter.M dan Meyer, Marshall. W, 2000, Birokrasi Dalam Masyarakat.

Gomes, Faustino Cardoso. 2000. Manajemen Sumber Daya Manusia. Yogyakarta : Andi Offset.

Kartasasmita, Ginanjar 1995, Pembangunan Menuju Bangsa Yang Maju Dan Mandiri, Pidato Ilmiah Penerimaan Gelar Dr. HC dalam Ilmu Administrasi Pembangunan DariUniversitas Gajah Mada, 15 April 1995.

Maso'ed, Mohtar dan Colin McAndrew, 1990, Perbandingan Sistem Politik, Yogyakarta: Gadjah Mada University Press

Makmur H. 2007, Patologi Serta Terapinya Dalam Ilmu Administrasi Dan Organisasi, Bandung : PT Refika Aditama

Nawawi, H, Haari. 2000. Manajemen Sumber Daya Manusia Untuk Bisnis Yang Kompetitif. Yogyakarta : Gajah Mada University Press.

Ndraha, Talidziduhu, 2003, Kybernology I (Ilmu Pemerintahan Baru), Jakarta : PT. Asdi Mahasatya,

2003, Kybernologi 2 (Ilmu

Pemerintahan Baru ), Jakarta : PT. Asdi Mahasatya

Osborne, David dan Ted Gaebler, 1996, Mewirausahakan Birokrasi, Jakarta : Pustaka Binaman Pressindo,

Osborne, David dan Peter Plastrik, 2000, Memangkas Birokrasi, Jakarta: Penerbit PPM,

Santoso, Priyo Budi, 1999, Birokrasi Pemerintah Orde Baru : Perspektif Kultural dan Struktural, Jakarta : Rajawali Press, 
Setiono, Budi, 2002, Jaring Birokrasi, Bekasi : Peraturan Pemerintah Nomor 101 Tahun PT. Gugus Press, 2000 Tentang Pendidikan Dan Pelatihan Jabatan Pegawai Negeri Sipil

Siagian Sondang, 1989, Patologi Birokrasi. Jakarta : Bumi Aksara

Notoatmodjo Soekidjo, 2002, http:// bejocommunity.blogspot.com

Syafiie. Kencana Inu, 2004, Birokrasi Pemerintahan Indonesia, CV. Mandar Maju, Bandung. (Lembaran Negara Nomor 4901)

Peraturan Menteri Pendayagunaan Aparatur Negara Nomor 66 Tahun 2005 Tentang Jabatan Fungsional Widyaiswara Dan Angka Kreditnya

UU No. 13 /2003 Pasal 1 ( 10 ) Tentang Ketenagakerjaan

Syani Abdul, 2002, Sosiologi (Skematika, Teori dan Terapan), Jakarta : PT. Bumi Aksara,

Syuhadhak, Mokhamad. 1994, Administrasi Kepegawaian Negara. Jakarta : Gunung Agung

Thoha, Miftah, 2002, Persepktif Perilaku Birokrasi, Jakarta : PT. Raja Grofindo Persada,

Birokrasi dan Politik di Indonesia, 2003, Jakarta : PT. Raja Grafindo Persada,

\section{Dokumen- dokumen}

Bahankuliah.blogsome.com File://C://Users/ Windows7/Dokuments/perpuhttp:// wardana-sl.blogspot.sains

Peraturan Pemerintah Rebublik Indonesia Nomor 72 Tahun 2005 Tentang Desa.

PERMENDAGRI No.4 Tahun 2007 Tentang Pedoman Pengelolaan Kekayaan Desa.

Peraturan Daerah No. 20 Tahun 2007 tentang Sumber Pendapatan dan Kekayaan Desa.

(http://pinterdw.blogspot.com/2012/03/ unsur-unsur-desa.html?=1diakses 26/ 06/2012 pukul 21.41 wita).

(http://www.sloetan.com/2012/01/26/ pembentukan-desa/ diakses tgl 26/ 06/2012 pukul 21.32 wita).

Bintarto. http://id.shvoong.com/social-sciences/1995187-pengertian-desa-danciri-cirinya/\#ixzz1yK421noq diakses tgl 01/07/2012 pukul 22.09 wita. 